\title{
Peran Ekspresi Interleukin (IL)-4 dalam Apoptosis Epitel Bronkiolus Mencit Asma
}

\section{The Role of Interleukin (IL)-4 Expression in Apoptosis Bronchiolus Epithelial in Asthmatic Mice}

\author{
Runiawan Condro $S^{1}, H M S$ Chandra Kusuma ${ }^{2}$, Teguh Wahju $S^{3}$ \\ ${ }^{1}$ Laboratorium IImu Kesehatan Anak Rumah Sakit Umum Dr. Saiful Anwar Malang \\ 2Laboratorium IImu Kesehatan Anak Rumah Sakit Umum Dr. Saiful Anwar Malang \\ ${ }^{3}$ Laboratorium Parasitologi Fakultas Kedokteran Universitas Brawijaya Malang
}

\begin{abstract}
ABSTRAK
Inflamasi kronis pada asma merupakan salah satu faktor yang mempengaruhi keparahan, eksaserbasi, dan remodeling jalan nafas yang ditandai peningkatan apoptosis epitel bronkiolus. Interleukin (IL)-4 merupakan salah satu sitokin tipe Th2 yang merupakan petanda proses inflamasi. Tujuan penelitian ini adalah untuk membuktikan hubungan antara ekspresi IL4 dan apoptosis epitel pada bronkiolus mencit asma. Penelitian dilakukan dengan desain randomized control group menggunakan 18 mencit galur Balb/c yang dibagi dalam kelompok asma dan kontrol. Kelompok asma disensitisasi dengan ovalbumin secara intraperitoneal pada hari ke-0 dan 14, diikuti dengan cara inhalasi setiap 2-3 hari selama 6 minggu. Ekspresi IL-4 pada bronkiolus diperiksa dengan metode imunohistokimia, sedangkan apoptosis epitel bronkiolus dengan metode TUNEL. Analisis statistik menggunakan independent sample t-test, Mann-Whitney $U$ test, dan regresi linier dengan interval kepercayaan 95\%. Jumlah apoptosis epitel bronkiolus dan ekspresi IL-4 meningkat bermakna pada kelompok asma $(p=0,000)$.Terdapat korelasi positif kuat $\left(r=0,78 ; r^{2}=0,56, p=0,012, y=4,28+0,58 \mathrm{x}\right)$ antara IL-4 dan apoptosis epitel pada bronkiolus. Peningkatan ekspresi IL-4 mempengaruhi peningkatan apoptosis epitel bronkiolus, namun bukan merupakan satu-satunya variabel yang mempengaruhi peningkatan apoptosis epitel bronkiolus.
\end{abstract}

Kata Kunci : Asma, apoptosis epitel, bronkiolus, IL-4, mencit ovalbumin

\begin{abstract}
Chronic inflammation in asthma is one of the factors that influence the severity, exacerbation, and airway remodeling marked increase in bronchial epithelial apoptosis. Interleukin (IL) -4 is a cytokine which is a marker of Th2 type of inflammatory process. The purpose of this study was to prove the relationship between IL-4 expression and apoptosis in bronchial epithelium of asthmatic mice. The study was conducted with a randomized control group design using 18 mice strain Balb / c are divided into groups and control asthma). Disensitisasi asthma group with ovalbumin intraperitoneally on day 0 and 14, followed by inhalation every 2-3 days for 6 weeks. IL-4 expression in bronchial examined by immunohistochemical methods, whereas bronchial epithelial apoptosis by TUNEL method. Statistical analysis using independent sample t-test, Mann-Whitney $U$ test, and linear regression with 95\% confidence interval. The number of bronchial epithelial apoptosis and expression of IL-4 increased significantly in the asthma group ( $p=0.000)$. There is a strong positive correlation ( $r=0.78 ; r 2=0.56, p=0.012, y=4.28+0.58 x$ ) between IL-4 and apoptosis in bronchial epithelium. Increased expression of IL-4 influence the increase in bronchial epithelial apoptosis, but not the only variable that affects the bronchial epithelium increased apoptosis.
\end{abstract}

Keywords: Asthma, bronchiolus, epithelial apoptosis, IL-4, mice, ovalbumin

Jurnal Kedokteran Brawijaya, Vol. 26, No. 2, Agustus 2010; Korespondensi: Runiawan Condro S. Laboratorium ilmu Kesehatan Anak, Rumah Sakit Umum Dr. Saiful Anwar Malang, Jl. Jaksa Agung Suprapto No. 2, Tel. (0341) 343343 Email: runiawancs@gmail.com 


\section{PENDAHULUAN}

Asma merupakan salah satu penyakit kronis tersering yang menjadi masalah di seluruh dunia, dengan prevalensi diperkirakan mencapai 300 juta orang dan mortalitas mencapai 250.000 orang per tahun (1-3). Sebagai gangguan inflamasi kronik saluran respiratorik, banyak sel yang berperan dalam patogenesis asma, khususnya sel mast, eosinofil, dan limfosit-T(4). Kegagalan meredanya proses inflamasi setelah terjadinya eksaserbasi merupakan masalah utama pada asma. Inflamasi kronis atau persisten ini merupakan salah satu faktor utama yang mempengaruhi tingkat keparahan dan frekuensi eksaserbasi, serta berperan dalam remodeling jalan nafas, hipertrofi otot polos, dan hipereaktivitas jalan nafas $(5,6)$. Salah satu mekanisme yang diduga berperan dalam kronisitas asma adalah dominasi dari alergen spesifik $\mathrm{CD}^{+}$yang memproduksi sitokin tipe Th2 (IL-4, IL5, IL-9, IL-13) (7-11). Sitokin tersebut berperan dalam respon inflamasi dengan merangsang sel inflamasi, meliputi sel mast, eosinofil, dan neutrofil $(12,13)$. Hal ini akan berpengaruh terhadap keseimbangan Th1 dan Th2 yang akan membawa pada proses apoptosis (kematian sel terprogram) epitel bronkiolus $(14,15)$.

Pengetahuan tentang patologi, patofisiologi, dan imunologi asma berkembang sangat pesat, tetapi mekanisme dasar perkembangan penyakit ini masih belum jelas. Peningkatan produksi sitokin yang dihasilkan Th2, antara lain IL-4 pada asma maupun terjadinya apoptosis epitel pada bronkiolus telah banyak diketahui, tetapi hubungan antara keduanya masih menjadi kontroversi dan belum pernah diteliti $(16,17)$. Penelitian in vivo oleh Nials dan Uddin (2008), dan Wegmann (2008) pada mencit galur BALB/c yang diinduksi dengan ovalbumin menemukan respon imunologis yang diperantarai aktivasi Th2 oleh sel CD4 ${ }^{+}$(18-20). Bucchieri (2002) menjelaskan bahwa apoptosis epitel bronkiolus merupakan salah satu tanda reaksi inflamasi saluran nafas yang tidak secara langsung diperantarai oleh pelepasan sitokin proinflamasi IL-4 sebagai respon aktivasi sel Th2 (21). Penelitian Corrigan (2008) menyatakan bahwa IL-4, IL-13, dan TGF- $\beta$ juga memegang peranan dalam apoptosis epitel bronkiolus dan remodeling jalan nafas (22).

Penelitian ini dilakukan secara in vivo pada subjek asma untuk mengetahui apakah ekspresi IL-4 pada asma berperan dalam apoptosis epitel bronkiolus. Subjek yang digunakan dalam penelitian ini adalah mencit galur Mus musculus (Balb/c mice) yang merupakan hewan model yang baik untuk menggambarkan kondisi asma pada manusia $(18,19)$. Telah diuji bahwa paparan antigen ovalbumin (OVA) menunjukkan adanya fenomena hiperesponsif saluran nafas (airway hyperresponsiveness (AHR), peningkatan sel-sel radang pada mukosa saluran nafas mencit, serta adanya peningkatan resistensi saluran nafas, yang ketiganya merupakan patofisiologi terjadinya asma pada manusia (18-20, 23-27).

\section{METODE}

\section{Preparasi Bakteri}

Penelitian dilakukan dengan randomized control group design, di Laboratorium Farmakologi dan Biomedik Fakultas Kedokteran Universitas Brawijaya Malang. Persetujuan etik diperoleh dari Panitia Etik Penelitian
Kedokteran Fakultas Kedokteran Universitas Brawijaya, RSU dr. Saiful Anwar, Malang. Mencit betina galur Mus musculus (Balb/c mice) yang memenuhi kriteria inklusi sebanyak delapan belas ekor dibagi menjadi dua kelompok, yaitu: kelompok perlakuan (9 mencit) dan kelompok kontrol (9 mencit) dengan teknik simple random sampling. Hasil uji pada kedua kelompok menunjukkan distribusi karakteristik yang homogen $(p=0.617)$ dari aspek jenis kelamin, umur, berat badan.

Tabel 1. Karakteristik hewan coba

\begin{tabular}{ccc}
\hline Karakteristik & Pe rlakuan & Kontrol \\
\hline Usia (minggu) & $8-10$ & $8-10$ \\
Jeniskelamin & Betina & Betina \\
Berat (g) & $26,20 \pm 1,90$ & $26,81 \pm 3,06$ \\
$P$ value & & $p=0,617$ \\
\hline
\end{tabular}

Pada kelompok perlakuan dilakukan sensitisasi dengan ovalbumin SERVA dan Aluminum hydroxide (alum) sebagai adjuvant yang membuat efek alergen ovalbumin bertambah kuat dan sensitisasi berlangsung lebih lama(18,19,26,28). Sensitisasi awal dilakukan secara intraperitoneal dengan menyuntikkan campuran $10 \mu \mathrm{g}$ ovalbumin $(\mathrm{OVA})+1 \mathrm{mg} \mathrm{Al}(\mathrm{OH})_{3}$ yang dilarutkan dalam 0,5 $\mathrm{ml}$ normal saline ( $\mathrm{NaCl} 0,9 \%$ )pada hari ke-0 dan hari ke-14. Sensitisasi ulangan dilakukan secara inhalasi dengan memberikan ovalbumin (OVA) $1 \%$ dalam normal saline $(\mathrm{NaCl} 0,9 \%)$ sebanyak $8 \mathrm{ml}$ per perlakuan dengan menggunakan nebulizer OMRON tipe NU-017 selama 20 menit dengan air flow volume dan nebulization volume pada skala 1. Sensitisasi secara inhalasi tersebut diulang selama 6 minggu sesuai jadwal setiap 2 hari mulai hari ke 2 hingga 59 pada waktu yang kurang lebih sama pada tiap perlakuan, antara pukul 09.00-11.00 WIB.

Setelah 8 minggu, seluruh hewan coba pada kedua kelompok diterminasi dengan cara diambil darah melalui jantungnya, setelah sebelumnya diberikan obat anestesi ketamin dan midazolam. Organ paru mencit difiksasi dengan formalin $10 \%$, selanjutnya dibuat sediaan histopatologi dan dilakukan pengamatan ekspresi IL-4 dan apoptosis epitel pada bronkiolus mencit dengan pengecatan imunohistokimia, menggunakan mikroskop cahaya pembesaran 1000x, sebanyak 20 lapangan pandang $(29,30)$. Hasil setiap perhitungan ditulis pada lembar kerja dan diambil nilai rata-rata per 20 lapangan pandang. Pemeriksa terdiri dari 2 orang ahli patologi anatomi, yang melakukan pemeriksaan dan perhitungan sampel secara terpisah. Sel yang mengekspresikan IL-4 menunjukkan warna coklat pada sitoplasmanya. Sel epitel yang mengalami apoptosis memiliki karakteristik berinti tunggal, perbandingan inti dan sitoplasma 3:4, dengan sitoplasma berwarna merah, dan inti sel berwarna coklat gelap.

Beda rerata jumlah ekspresi IL-4 pada bronkiolus dan kadar IgE OVA antara kedua kelompok dianalisis dengan independent-sample t-test. Distribusi data dianalisis menggunakan Shapiro-Wilk test karena jumlah sampel kurang dari 50. Jumlah apoptosis epitel dianalisis dengan Mann-Whitney $U$ test karena distribusi tidak normal pada 
kelompok kontrol. Pengaruh ekspresi IL-4 dengan apoptosis epitel bronkiolus dianalisis menggunakan uji regresi linier pada confidence interval 95\%. Semua data diolah dengan menggunakan SPSS 17.0 for windows.

\section{HASIL}

\section{Gambaran Apoptosis Epitel dan Ekspresi IL-4 pada} Bronkiolus Balb/c Mice

Pada pengamatan sediaan histopatologi, didapatkan peningkatan jumlah apoptosis epitel pada bronkiolus mencit yang disensitisasi dengan ovalbumin. Hal ini ditunjukkan dengan gambaran sel yang mengalami apoptosis lebih banyak (panah merah pada Gambar 1). Ekspresi IL-4 pada bronkiolus tampak pada sel-sel yang berwarna coklat pada sitoplasmanya. Didapatkan peningkatan ekspresi IL-4 pada kelompok perlakuan (mencit yang disensitisasi dengan ovalbumin) dibandingkan kelompok kontrol. Gambar 2 menunjukkan jumlah sel dengan sitoplasma berwarna coklat lebih banyak pada kelompok perlakuan. Sebaran sel dengan sitoplasma coklat juga lebih pada kelompok perlakukan (panah merah besar).
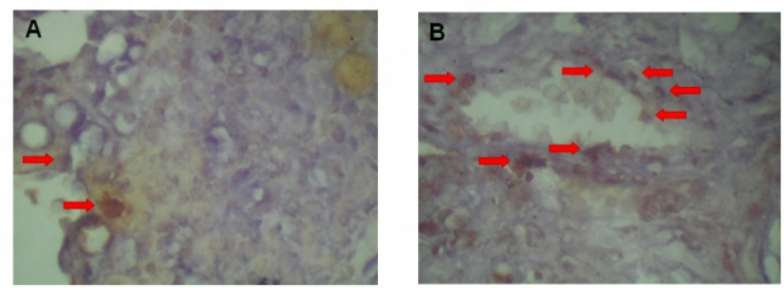

Gambar 1. Gambaran Apoptosis Epitel pada Bronkiolus Mencit Panah merah menunjukkan sel yang mengalami apoptosis pada bronkiolus mencit kontrol (A) dan pada bronkiolus mencit yang telah disensitisasi dengan ovalbumin (B)
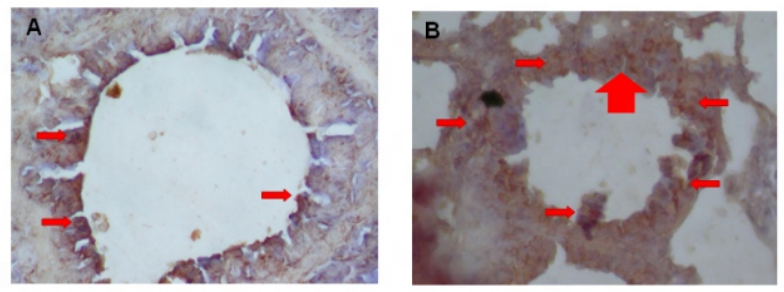

Gambar 2. Gambaran Ekspresi IL-4 pada Bronkiolus Mencit

Panah merah menunjukkan ekspresi IL-4 pada mencit kontrol (A); dan mencit yang telah disensitisasi dengan ovalbumin (B).

\section{Perbandingan Ekspresi IL-4, Apoptosis Epitel, dan Ekspresi} IgE OVA antara Kelompok Perlakuan dan Kontrol

Pada pengamatan, didapatkan ekspresi IL-4 lebih tinggi pada kelompok asma $(p<0.001)$. Secara kuantitatif apoptosis epitel bronkiolus pada kelompok perlakuan (asma) lebih tinggi secara signifikan $(p=0.001)$ dibandingkan kontrol. Demikian juga kadar IgE OVA, kelompok perlakuan (asma) lebih tinggi ( $p=0.001)$ dibandingkan kelompok kontrol (Tabel 2). Secara keseluruhan pada asma terjadi peningkatan apoptosis,
IgE, dan ekspresi IL-4.

Tabel 2. Perbandingan ekspresi IL-4, apoptosis epitel, dan ekspresi IgE OVA pada kelompok perlakuan dan kontrol

\begin{tabular}{|c|c|c|c|}
\hline Variabel & $\begin{array}{l}\text { Perlakuan } \\
\text { (Mean } \pm \text { SD) }\end{array}$ & $\begin{array}{l}\text { Kontrol } \\
\text { (Mean } \pm \\
\text { SD) }\end{array}$ & $P$ value \\
\hline $\begin{array}{l}\text { IL-4 (rata- } \\
\text { rata sel/20 lap. } \\
\text { pandang) }\end{array}$ & $16,61 \pm 2,73$ & $\begin{array}{c}4,33 \pm \\
2,22\end{array}$ & $\begin{array}{c}p=0,000 \\
\text { (Independent } t \text {-test) }\end{array}$ \\
\hline $\begin{array}{c}\text { Apoptosis Epi tel } \\
\text { (rata-rata sel/20 } \\
\text { lap. pandang) }\end{array}$ & $13,89 \pm 2,01$ & $\begin{array}{c}3,06 \pm \\
0,68\end{array}$ & $\begin{array}{c}p=0,000 \quad \text { (Mann } \\
\text { Whitney U test) }\end{array}$ \\
\hline IgE OVA(IU/mI) & $11,22 \pm 2,30$ & $\begin{array}{c}7,60 \pm \\
1,13\end{array}$ & $\begin{array}{c}p=0,001 \text { (Independent } \\
\text { t-test) }\end{array}$ \\
\hline
\end{tabular}

Uji regresi menunjukkan pengaruh signifikan $(p=0.012$, $\mathrm{B}=0.58$ ) ekspresi IL-4 dan apoptosis epitel pada bronkiolus mencit kelompok perlakuan. Variasi apoptosis epitel pada bronkiolus dapat dijelaskan oleh ekspresi IL-4 sebesar $56 \%$.

\section{DISKUSI}

Pada asma, pergeseran keseimbangan respon imuni tipe 1 ke tipe 2 akan memodulasi eosinofilia, produksi IgE, Airway Hyperresponsiveness (AHR), dan inflamasi kronik. Pada pasien asma didapatkan peningkatan produksi sitokin tipe 2 yang diwakili oleh IL-4. Interleukin (IL)-4 merupakan salah satu sitokin kunci pada asma dan pada patogenesis reaksi alergi lainnya. Ekspresi IL-4 berperan dalam menstimulasi diferensiasi sel T CD4 ${ }^{+}$naïve menjadi sel Th2, proliferasi atau ekspansi klonal sel Th2, menstimulasi switching limfosit-B dalam memproduksi IgE, meningkatkan ekspresi reseptor IgE (FcERI) pada limfosit-B dan sel fagosit mononuklear, serta FceRII pada sel mast dan basofil, setelah paparan antigen (10,31,32). Pada asma, IL-4 mampu menstimulasi fibroblas untuk memproduksi eotaxin dan sitokin-sitokin pro-inflamasi yang menyebabkan terjadinya remodeling saluran nafas serta meningkatkan ekspresi VCAM-1 pada endotel vaskuler. Melalui interaksi VCAM-1, IL-4 secara langsung menyebabkan migrasi limfosit-T, monosit, eosinofil, dan basofil ke daerah inflamasi (10). Interleukin (IL)-4 juga mampu menghambat apoptosis limfosit-T. Persistensi dan aktivasi limfosit-T (sel Th2) ini menimbulkan umpan balik positif (positive feed back) dengan semakin meningkatnya produksi IL-4 diikuti peningkatan diferensiasi dan ekspansi klonal sel Th2 (33). Pada penelitian ini, didapatkan ekspresi IL-4 yang lebih tinggi pada kelompok asma. Hal ini menunjukkan adanya peningkatan produksi IL-4 pada subjek asma yang disebabkan oleh provokasi alergen akibat adanya peningkatan proliferasi dan penghambatan apoptosis limfosit, terutama sel Th2 sebagai produsen utama IL-4. Peningkatan IL-4 ini diikuti oleh peningkatan kadar IgE, dalam hal ini IgE ovalbumin. Pada penelitian ini, didapatkan kadar IgE ovalbumin yang yang lebih tinggi pada kelompok asma (IgE OVA: $p=0,001$ ). Peningkatan kadar IL-4 pada subjek asma didukung oleh penelitian Brown, dkk (2005). Brown melakukan pemeriksaan pada serum dan Broncho Alveolar Lavage (BAL) menunjukkan peningkatan kadar IL-4 pada subjek alergi (34). 
Peningkatan IL-4 yang terjadi pada penderita asma tersebut bukan sekedar akibat dari provokasi allergen. Beberapa penelitian menunjukkan adanya perubahan regulasi dalam produksi IL-4 pada subjek atopi. Penelitian oleh Parronchi, dkk (1992) secara in vitro pada klon limfosit $\mathrm{T} \mathrm{CD}^{+}$setelah paparan dengan antigen bakterial menunjukkan adanya produksi IL-4 pada subjek atopi, sedangkan pada subjek non-atopi didapatkan produksi sitokin Th1 (35). Data ini diperkuat oleh penelitian Chan, dkk (1996) yang menunjukkan tingginya frekuensi limfosit-T yang memproduksi IL-4 pada subjek atopi dibandingkan subjek normal (36); serta penelitian oleh Piccinni, dkk (1996) yang menunjukkan tingginya produksi IL-4 oleh limfosit-T pada darah umbilikal neonatus dengan orang tua atopi, dibandingkan dengan neonatus dengan orang tua non-atopi $(36,37)$. Berbagai temuan tersebut menunjukkan bahwa patogenesis asma bukan sekedar disebabkan oleh provokasi alergen, namun disebabkan pula oleh adanya perubahan regulasi produksi IL-4 yang berkaitan dengan perubahan genetik, terutama kromosom 5q31-33 (10) Pada penelitian ini, hewan coba yang digunakan adalah mencit normal (Balb/c mice) dengan provokasi alergen (IgE ovalbumin), sehingga IL-4 yang dihasilkan adalah murni akibat sensitisasi alergen.

Pada respon imun saluran nafas penderita asma, sensitisasi antigen akan menyebabkan denudation dan kerusakan dari epitel saluran napas bagian bawah, terutama pada bronkiolus. Hal ini akan menyebabkan proses remodeling jalan napas yang dihubungkan dengan proses inflamasi kronis pada asma antara lain: deposisi kolagen (fibrosis), hiperplasi fibroblas, proliferasi sel goblet, hiperplasi kelenjar mukus, hipertrofi/hiperplasi otot polos, apoptosis epitel bronkiolus, dan neovaskularisasi $(14,27)$. Pada penelitian dari Spinozzi, dkk (2008) remodeling jalan napas pada asma menunjukkan bahwa apoptosis epitel pada jalan napas terjadi lebih dahulu, mengawali infiltrasi dari limfosit yang mengarah pada pembentukan mukus pada jalan napas. Pada subyek asma, terjadi peningkatan apoptosis epitel jalan napas setelah sensitisasi antigen disertai penurunan jumlah apoptosis limfosit pada saluran napas (14). Pada penelitian ini didapatkan perbedaan jumlah epitel bronkiolus yang mengalami apoptosis pada kelompok asma (alergi) dan kontrol. Hal ini dapat disebabkan pada kelompok normal (kontrol) tidak dilakukan sensitisasi antigen sehingga tidak terjadi peningkatan proliferasi limfosit sehingga tidak terjadi pula proses inflamasi yang diperantarai sitokin-sitokin dari sel Th2. Pada kelompok asma, setelah dilakukan sensitisasi antigen, didapatkan jumlah apoptosis epitel bronkiolus dengan jumlah yang lebih banyak dibandingkan kelompok kontrol. Hal ini sesuai dengan penelitian yang dilakukan oleh Holgate, dkk (2000) dan Corrigan, dkk (2008) yang menyatakan bahwa pada asma, epitel bronkiolus memperlihatkan bukti kerusakan yang ditandai dengan hilangnya sel kolumnar dari lapisan sel basal dan memicu terjadinya proses apoptosis dari epitel jalan napas $(16,22)$. Kerusakan epitel pada asma akan memberikan konsekuensi klinis karena epitel memegang peranan dan sumber yang penting dari mediator autacoid, chemokines, dan growth factors yang memberikan kontribusi pada terjadinya proses inflamasi dan aktivasi dari myofibroblas, yang akhirnya mengarah pada remodeling dari jaringan $(16,21)$.

Pada penelitian ini didapatkan adanya peningkatan ekspresi IL-4 disertai peningkatan apoptosis epitel bronkiolus dan peningkatan kadar IgE ovalbumin pada kelompok asma. Variasi peningkatan apoptosis epitel pada bronkiolus dipengaruhi oleh ekspresi IL-4 sebesar $56 \%$. Hal ini menunjukkan bahwa peningkatan apoptosis epitel bronkiolus tidak hanya dipengaruhi oleh IL-4, namun kemungkinan juga diperankan oleh interaksi banyak faktor secara kompleks, yang tidak diteliti pada penelitian ini. Belum pernah ada penelitian sebelumnya yang menghubungkan antara IL-4 dan apoptosis epitel bronkiolus pada asma. Beberapa penelitian lain dari Holgate dan Polosa (2008) menghubungkan antara peran IL-13, eosinofil, sel mast, dan aktivitas Th1 terhadap proses denudation epitel jalan nafas walaupun tidak menjelaskan secara eksplisit mengenai hubungannya dengan apoptosis epitel bronkiolus (9).

Peningkatan ekspresi IL-4 pada asma mampu menstimulasi produksi eotaxin dan sitokin pro-inflamasi oleh fibroblas yang menyebabkan terjadinya remodeling saluran nafas, serta meningkatkan ekspresi VCAM-1 pada endotel vaskuler yang menyebabkan migrasi sel-sel radang ke tempat inflamasi (10). Pada keadaan normal, sel epitel saluran nafas terdiri atas sel kolumnar bersilia, sel goblet yang memproduksi mukus, dan surfaktan yang semuanya membentuk satu kesatuan yang berperan sebagai impermeable barrier. Selain itu juga terdapat tight junction yang berlokasi pada bagian apeks dari sel kolumnar. Integritas struktural dari epitel tersebut dipelihara oleh sel-sel dan matriks ekstra selular termasuk desmosom dan hemidesmosom. Kerusakan dari epitel sel kolumnar ini menyebabkan kerusakan jaringan sehingga memungkinkan masuknya zat-zat yang bersifat merusak dan partikel infeksius masuk ke dalam dinding saluran nafas yang memicu reaksi toksik, imun maupun peradangan (38). Hal inilah yang dapat menjelaskan awal terjadinya proses remodeling saluran napas akibat stimulasi exotoxin dan sitokin pro-inflamasi oleh fibroblas yang dipicu oleh IL-4 pada sel epitel saluran napas. Pada awalnya ditandai oleh denudation dari sel epitel, kerusakan epitel sel kolumnar, masuknya zat-zat yang bersifat merusak dan partikel infeksius ke dalam dinding saluran napas yang memicu reaksi toksik, imun maupun peradangan, sehingga pada akhirnya memicu terjadinya apoptosis epitel bronkiolus dan diikuti kerusakan jaringan.

Peran protein pro dan anti-apoptotik dalam mengatur apoptosis epitel bronkiolus pada asma belum banyak dibuktikan oleh penelitian lain. Beberapa penelitian telah menunjukkan adanya peran $\mathrm{Bcl}-2$ sebagai protein antiapoptotik dalam menghambat apoptosis limfosit pada asma. Penelitian oleh Antonio, dkk (1999) dengan biopsi bronkus menunjukkan adanya peningkatan ekspresi Bcl-2 dan peningkatan jumlah limfosit-T yang berinfiltrasi ke submukosa saluran nafas subjek asma (39). Muller, dkk (2006) dengan pemeriksaan BAL juga menemukan adanya peningkatan ekspresi $\mathrm{Bcl}-2$ pada pasien atopi yang diprovokasi oleh alergen (40). Peningkatan ekspresi Bcl-2 ini salah satunya disebabkan oleh peningkatan kadar IL-4. Pada penelitian di atas, penghambatan apoptosis limfosit tersebut dipengaruhi oleh $\mathrm{Bcl}-2$ tersebut melalui ikatan terhadap Bax (protein pro-apoptotik) sehingga proses apoptosis dari limfosit dihambat dan manifestasi klinis asma muncul, namun berbeda halnya pada apoptosis epitel bronkiolus. Pada penelitian ini justru terjadi peningkatan apoptosis epitel bronkiolus akibat ekspresi IL- 
4, kemungkinan faktor yang mempengaruhi justru peningkatan jumlah protein pro-apoptotik. Hal ini masih belum dapat dijelaskan karena belum ada penelitian lain yang mengacu pada teori ini.

Desain penelitian ini merupakan penelitian in vivo, sehingga memberikan gambaran patogenesis dan patofisiologi asma yang lebih mirip dengan gambaran penyakit sesungguhnya dibandingkan dengan penelitian in vitro. Penggunaan mencit galur Mus musculus (Balb/c mice) cukup representatif untuk memberikan gambaran asma pada manusia karena mampu memberikan gambaran sensitisasi saluran nafas, inflamasi alergi yang diperantarai Th2, eosinofilia pada mukosa saluran nafas, dan $\operatorname{AHR}(18,19)$, serta didapatkan pula gambaran hiperplasia sel goblet, fibrosis sub-epitel dan peribronkial. Gambaran ini menetap setelah penghentian paparan alergen, serta didapatkan gambaran remodeling saluran nafas yang menetap $(23,24)$. Pada penelitian ini, diperoleh gambaran

\section{DAFTAR PUSTAKA}

1. Bateman ED, Hurd SS, Barnet PJ, et al. Global Initiative for Asthma: Global Strategy for Asthma Management and Prevention. European Respiratory Journal. 2008; 31(1): 143-178.

2. Rabe KF, Vermeire PA, Soriano JB, and Maier WC. Clinical Management of Asthma in 1999: The Asthma Insights and Reality in Europe (AIRE) Study. European Respiratory Journal. 2000; 16(5): 802-807.

3. Gern J, Lemanske RF, and Busse WW. Early Life Origins of Asthma. The Journal of Clinical Investigation. 1999; 104(7): 837-843.

4. Locke NR, Royce SG, Wainewright JS, Samuel CS, and Tang ML. Comparison of Airway Remodeling in Acute, Subacute, and Chronic Models of Allergic Airways Disease. American Journal of Respiratory Cell and Moleculer Biology. 2007; 36(5): 625-632.

5. Tagaya E and Tamaoki J. Mechanisms of Airway Remodelling in Asthma. Allergology International. 2007; 56: 331-340.

6. Rahajoe N, Supriyatno B, dan Setyanto DB. Pedoman Nasional Asma Anak. Jakarta: UKK Pulmonologi PP IDAI; 2004.

7. Elias JA, Lee CG, Zheng T, Ma B, Homer RJ, and Zhu Z. New Insights into the Pathogenesis of Asthma. The Journal of Clinical Investigation. 2003; 111(3): 291-297.

8. Kips JC. Cytokines in Asthma. European Respiratory of Journal. 2001; 18 (34 suppl): 24s-33s.

9. Holgate ST and Polosa R. Treatment Strategies for Allergy and Asthma. Nature Review Immunology. 2008; 8(3): 218-230.

10. Steinke JW and Borish L. Th2 Cytokines and Asthma. Interleukin-4: its Role in the Pathogenesis of Asthma, and Targeting it for Asthma Treatment with Interleukin-4 Receptor Antagonists. Respiratory Research. 2001; 2: 66-70.

11. Vella A, Teague TK, Ihle J, Kappler J, and Marrack P. Interleukin 4 (IL-4) or IL-7 Prevents the Death of Resting T Cells: Stat6 is Probably not Required for the pada kelompok perlakuan yang analog dengan gambaran asma pada manusia berupa sensitisasi saluran nafas pada mencit yang ditandai oleh adanya peningkatan IgE ovalbumin serta peningkatan sitokin Th2 yaitu IL-4. Kelemahan pada penelitian ini, penentuan apoptosis epitel maupun ekspresi IL-4 pada bronkiolus dilakukan secara subjektif berdasarkan morfologi tidak menggunakan petanda/marker reseptor IL-4 secara imunohistokimia metode serupa juga pernah dilakukan oleh Vandervalden walaupun telah digunakan metode pengecatan khusus secara imunohistokimia sebagai petanda apoptosis epitel dan ekspresi IL-4 pada bronkiolus (41). Dapat disimpulkan bahwa peningkatan ekspresi IL-4 dapat meningkatkan apoptosis epitel bronkiolus pada asma, namun IL-4 bukan merupakan satu-satunya faktor yang berperan. Adanya berbagai faktor yang secara kompleks saling berkaitan dalam mempengaruhi apoptosis epitel bronkiolus juga dipengaruhi oleh variabel lain yang hingga saat ini masih belum diteliti.

Effect of IL-4. The Journal of Experimental Medicine. 1997; 186(2): 325-330.

12. Vignola AM, Mirabella F, Costanzo G, et al. Airway Remodelling in Asthma. Chest. 2003; 123(3 suppl): $417 \mathrm{~s}-422 \mathrm{~s}$.

13. Tang MLK, Wilson JW, Stewart AG, and Royce SG. Airway Remodelling in Asthma: Current Understanding and Implications for Future Therapies. Pharmacology and Therapeutics. 2006; 112(2): 474488.

14. Spinozzi F, Benedictis DD, and Benedictis FD. Apoptosis, Airway Inflammation and Anti-Asthma Therapy: From Immunobiology to Clinical Application. Pediatric Allergy and Immunology. 2008; 19(4): 287295.

15. Lemanske RFJr. Inflammation in Childhood Asthma and Other Wheezing Disorders. Pediatrics. 2002; 109(suppl): 368-72.

16. Holgate ST, Davies DE, Lackie PM, Wilson SJ, Puddicombe SM, and Lordan JL. EpithelialMesenchymal Interactions in the Pathogenesis of Asthma. Journal of Allergy and Clinical Immunology. 2000; 105(2): 193-204.

17. Yunus F, Mangunnegoro $H$, dan Rahmawati I. Pedoman Diagnosis dan Penatalaksanaan Asma di Indonesia. Jakarta: FKUI; 2003.

18. Nials AT and Uddin S. Mouse Models of Allergic Asthma: Acute and Chronic Allergen Challenge. Disease and Model Mechanism. 2008; 1(4-5): 213220.

19. Barlianto W, Kusuma MSC, Karyono S, dan Mintaroem K. Pengembangan Model Mencit Alergi dengan Paparan Kronik Ovalbumin. Jurnal Kedokteran Brawijaya. 2009; 25(1): 2-5.

20. Wegmann M. Animal Models of Chronic Experimental Asthma - Strategies for the Identification of New Therapeutic Targets. Journal of Occupational Medicine and Toxicology. 2008; 3(Suppl 1): S4.

21. Bucchieri F, Puddicombe SM, Lordan JL, et al. Asthmatic Bronchial Epithelium is More Susceptible to Oxidant-induced Apoptosis. American Journal of 
Respiratory Cell and Molecular Biology. 2002; 27(2): 179-185.

22. Corrigan C. Mechanisms of Asthma. Medicine. 2008; 36(4): 80-177.

23. Kumar R and Foster P. Modelling Allergic Asthma in Mice. American Journal of Respiratory Cell and Molecular Biology. 2002; 27(3): 267-272.

24. McMillan SJ and Lloyd CM. Prolonged Allergen Challenge in Mice Leads to Persistent Airway Remodelling. Clinical and Experimental Allergy. 2004; 34(3): 497-507.

25. Boyce JA and Austen KF. No Audible Wheezing: Nuggets and Conundrums from Mouse Asthma Models. The Journal of Experimental Medicine. 2005; 201(12): 1869-1873.

26. Shinagawa K and Kojima M. Mouse Model of Airway Remodeling. American Journal of Respiratory and Critical Care Medicine. 2003; 168(8): 959-967.

27. Gueders M, Paulissen G, Crahay $\mathrm{C}$, et al. Mouse Models of Asthma: a Comparison between C57BL/6 and $B A L B / C$ Strains Regarding Bronchial Responsiveness, Inflammation, and Cytokine Production. Inflammation Research. 2009; 58(12): 845-854.

28. Zosky GR, Larcombe AN, White OJ, et al. OvalbuminSensitized Mice are Good Models for Airway Hyperresponsiveness but Not Acute Physiological Responses to Allergen Inhalation. Clinical and Experimental Allergy. 2007; 38(5): 829-838.

29. Pizem and A Cor. Detection of Apoptosis Cells in Tumour Paraffin Section. Radiology Oncology. 2003; 37(4): 225-232.

30. Soini Y, Paakko P, and Lehto VP. Histhopathological Evaluation of Apoptosis in Cancer. The American Journal of Pathology. 1998; 153(4): 1041-1048.

31. Abbas AK, Lichtman AH, and Pillai S. Cytokines. In: Abbas AK, Lichtman AH, Pillai S, (Ed). Cellular and Molecular Immunology 5th edition. Philadelphia: Saunders-Elsevier; 2007; p. 267-302.

32. Galli SJ, Grimbaldeston $M$, and Tsai $M$. Immunomodulatory Mast Cells: Negative, as Well as Positive, Regulators of Immunity. Nature Reviews Immunology. 2008; 8(6): 478-486.
33. Vella AT, Dow S, Potter TA, Kappler J, and Marrack P. Cytokine-Induced Survival of Activated T Cells In Vitro and In Vivo. Procedding of National Academy Science of The United State America. Washington, March 31, 1998; p. 3810-3815.

34. Brown VG and Ennis M. T Cell Cytokine Production in Childhood Asthma. Current Respiratory Medical Review. 2005; 1: 1-6.

35. Parronchi $P$, de Carli $M$, Manetti $R$, et al. Aberrant Interleukin (IL)-4 and IL-5 Production in Vitro by CD4 Helper T Cells from Atopic Subjects. European Journal of Immunology. 1992; 22(6): 1615-1620.

36. Chan SC, Brown MA, Wilcox TM, et al. Abnormal IL-4 Gene Expression by Atopic Dermatitis T Lymphocytes is Reflected in Altered Nuclear Protein Interactions with IL-4 Transcriptional Regulatory Element. The Journal of Investigative Dermatology. 1996; 106(5): 1131-1136.

37. Piccinni M-P, Beloni L, Giannarini L, et al. Abnormal Production of T Helper 2 Cytokines Interleukin-4 and Interleukin-5 by T Cells from Newborns with Atopic Parents. European Journal of Immunology. 1996; 26(10): 2293-2298.

38. Puddicombe SM, Polosa R, Richter $A$, et al. Involvement of the Epidermal Growth Factor Receptor in Epithelial Repair in Asthma. The Journal of Federation American Societies for Experimental Biology. 2000; 14: 1362-1374.

39. Antonio MV, Pascal C, Giuseppina C, et al. Evaluation of Apoptosis of Eosinophils, Macrophages, and $T$ Lymphocytes in Mucosal Biopsy Specimens of Patients with Asthma and Chronic Bronchitis. The Journal of Allergy and Clinical Immunology.1999; 103(4): 563573.

40. Müller M, Grunewald J, Olgart Höglund C, Dahlén B, Eklund A, and Stridh H. Altered Apoptosis in Bronchoalveolar Lavage Lymphocytes after Allergen Exposure of Atopic Asthmatic Subjects. The European Respiratory Journal. 2006; 28(3):513-522.

41. Van der Velden VHJ, Naber BAE, Wierenga-Wolf AF, et al. Interleukin 4 Receptors on Human Bronchial Epithelial Cells. An in Vivo and in Vitro Analysis of Expression and Function. Cytokine. 1998; 10(10): 803813. 